\title{
Teaching Gender Responsiveness through Folktales in EFL Classroom
}

\author{
Qanitah Masykuroh \\ \{qanitah.masykuroh@ums.ac.id\} \\ Department of English Education, Universitas Muhammadiyah Surakarta, Jl. A Yani Tromol Pos 1 \\ Pabelan Surakarta, Indonesia
}

\begin{abstract}
Folktales are believed to one of can allow students to think critically about aspects of life in their own communitiesThe purpose of this study is to explore the utilization of Indonesian folktales in the EFL classroom for junior high school students.. Hence, the data of the study comprises the document, and information collected from observation and interview from an EFL class at an Islamic Junior high school in Surakarta, Central Java. The result shows that the use of selected folktales in the EFL classroom can provide and trigger more English language use. Moreover, the gender themes of the folktales can also be used to initiate students to think critically on gender issues, relating the folktales to their daily life experience. Further, this can help the students foster critical literacy as well as teaching them with a further understanding of gender notions in their lives. This study confirms the advantage of teaching ELT which encompass not only linguistic elements but also the integration of traditional literature in the curricula.
\end{abstract}

Keywords: gender responsiveness, folktales, teaching EFL

\section{Introduction}

Folktales as parts of children's literatures have long been interplayed between entertaining and educating children. The specific features of its narrative makes folktales stick to children imagination and fantasy. Moreover, it is widely believed that folktales contain the values which are believed to be a good source of socialization for children [1] as well as to impose national identity [2].

To pass down such valuable cultural norms, folktales have been selected as media in children education one of which in the context of learning in ESL/EFL classrooms [3].The utilization of traditional tales not only can improve students' literacy, but can also help students construct a narratives repertoire as well as building a world of their own. However, there have been many researches pointing out that folktales still depict the prevalent image of gender bias [4] [5] [6] as well as gender-based violence [7] [8] [9], and the use of such folktales in teaching, has been a continuous debate amongst researchers and educators.

Correspondingly, putting the gender issues in EFL classrooms have been an increasing trends considering the significance of gender literacy for the youth. Notwithstanding the possible gender insensitive content, the use of folktales as media for introducing gender issue and enhancing gender awareness to students has been developing [10] [11] [12] together with the growing interest to bring in multicultural literatures in EFL Classroms. 
In the study, the teaching in EFL classroom deployed Contextual Teaching and Learning (CTL) which would enable students to relate what they are learning in the classroom to the application of their knowledge in their real life as a member of a society [12]. In addition, the learning process helps students see aspects of meaning of real life in the material they are learning [13].

By combining folktales and CTL teaching, this study aims at providing an alternative of the utilization of folktales in view of gender responsiveness which will help students foster their critical thinking and literacy by better understanding the issue and problem of stereotyped female roles in the context of Indonesian culture and gender notions in their society.

\section{Methodology}

The participants of the study are two classes of grade VII at SMP Muhammadiyah Surakarta, Special Program. In the study, each of folktales video of Si Comel, Pangeran Katak, and Timun Mas was played in three meetings. The videos serve to elicit students' critical thinking on gender issues. The steps which comprise pre-viewing, whilst viewing and post viewing are used to guide students focusing on the gender issues in the folktales. In addition, the application of CTL strategies i.e. relating, experiencing, applying, cooperating and transfering are also used during the exploration of the gender issues after the video. While learning the gender issues, in all those steps students also practice their English skills.

\section{Finding and Discussion}

The folktales selected to play in the videos i.e. Si Comel, Pangeran Katak and Timun Mas depict heroines who are beautiful, kind, and industrious. Nevertheless, Si Come land Pangeran Katak portray weak and passive heroine while Timun Mas portrays a resourceful heroine.

Si Comel depicted a story which is resemblance with the western canonical story Cinderella in which the heroine was a beautiful, kind and industrious girl who faced the hatred of her stepmother and her two stepsisters. Her kindness and enduring life hardship was then rewarded by the marriage proposed by a prince charming.

Having quite same kind of main female character, Pangeran Katak outlined a story of a princess who was kind and beautiful. One day she accidentally dropped her bracelet in a pond and a frog tuned up to help her get her bracelet back. However, the help was on one condition that the princess let the frog to stay with her. To keep her promise, the princess let the frog be her daily companion in the palace.

Differently, Timun Mas depicted a resourceful girl who is not only beautiful, kind and industrious but also strong and brave. The story outlined a girl who was a gift from a giant to a widow, providing that when the girl was grown up, the widow must give her back to the giant to consume. The baby girl was found in a cucumber. When the time came, the mother asked the girl to see a saint for help and was given three pockets of seeds. Using those seeds, the girl fought the giant and finally, she could defeat him.

In general, the use of folktales video in the EFL classroom seemed interesting for the students and successfully attracted students' attention. The students' interest was also due to the fact those, except Timun Mas, the two other folktales were not quite familiar for them. This confirms what [4] and [14] studied that despite the rich Indonesia folktales available, many of them have not been presented and explored for wide audience of Indonesian children. The popular folktales used in school textbook are usually selected considering their use as a means to impose character education and national identity [15]. Correspondingly, although the publishing of Indonesian folktales has been flourishing, the affordability of such books is still low. 
Preceding the video viewing, the students are told the points they had to notice and concern while they were watching the video. Then, after watching, they retold the synopsis of the story and shared the description of the characters in the folktales as well. At this step, the teacher provided the enrichment of vocabularies used in describing people which include adjectives used to describe as well as to discuss people's appearance, attitude and behaviour.

In discussion section, the students are divided into groups and guided with questions related to gender issues. The description of the characters used the vocabularies which were mainly adjectives. In addition, the description included both physical and behaviour, and the description of the behaviour comprised two aspects i.e. personal behaviour in nature and behaviour in social interaction.

The followings are the questions on gender issues discussed by the students:

Table 1. Si Comel questions on the gender issues

\begin{tabular}{|l|l|}
\hline Video & Si Comel \\
\hline $\begin{array}{l}\text { The gender issue } \\
\text { explored using this } \\
\text { video }\end{array}$ & The topic of stereotyping girls. \\
\hline The questions: \\
How is the characteristic of the female characters, the protagonist and the antagonist, in the \\
story? \\
Can you find people in your daily life who have the similar character? \\
What do you think about such character? \\
What do you think the way the heroine can do to find happiness/save her life? \\
Using your own experience in your daily life, what do you think a girl can do to find \\
happiness/to be successful? \\
In your own community, what are the social expectations of girls? \\
\hline
\end{tabular}

The exploration of questions on the gender issues in video 1, Si Comel above led the students to recognize and think critically about the gender bias in the story. They found the girls stereotyping in which on one hand, the kind girl (the protagonist) is weak and passive, waiting for a helper to save her from hardship and to get a happy life in a form of a happy marriage. On the other hand, the unkind girls' characters (the stepsisters) are more active, but because of their wickedness, they didn't get reward a happy marriage with princes charming. This kind of stereotyping seems to be prevalent either in western canonical folktales [15] [6] or in Indonesian folktales [4] [16].

Further the students contextualize this gender stereotyping with their experience in daily life, finding that although some of situation were similar, what they found in the society was more complex. The discussion on video folktales 1 resulted in two concluding and suggesting ideas of how to empower girls which comprise first, to be active, to be independent and to be brave; second, to confirm society expectation i.e. to be kind and to care for other people.

Table 2. Pangeran Katak questions on the gender issues

\begin{tabular}{|l|l|}
\hline Video 2 & Pangeran Katak \\
\hline $\begin{array}{l}\text { The gender issue } \\
\text { explored using this } \\
\text { video }\end{array}$ & $\begin{array}{l}\text { The topic of interaction } \\
\text { between girls and boys. }\end{array}$ \\
\hline
\end{tabular}




The questions:
How is the characteristic of the main male and female characters in the story?
Can you find people in your daily life who have the similar character?
What do you think of such character?
How is the male character different from the female character?
How does gender play roles in the interaction between the main female character and the
main male character?
What kind of interaction between girls and boys can you find in your daily life?
What do you think about the mutual interaction between girls and boys?

The exploration of questions on the gender issues in video 2, Pangeran Katak gave the students' insights of how gender stereotyping is different male and female and how gender played roles in social interaction between males and females. They also discuss the possibility of how the relationship between male and female can be mutual.

Table 3. Timun Mas questions on the gender issues

\begin{tabular}{|c|c|}
\hline Video & Timun Mas \\
\hline $\begin{array}{l}\text { The gender issue } \\
\text { explored using this } \\
\text { video }\end{array}$ & Social expectation and non-conforming characters \\
\hline $\begin{array}{l}\text { The questions: } \\
\text { How is the characte } \\
\text { Can you find peopl } \\
\text { How is the female c } \\
\text { What do you think } \\
\text { How do you find pe } \\
\text { your daily life? }\end{array}$ & $\begin{array}{l}\text { f the main female character in the story? } \\
\text { ir daily life who have the similar character? } \\
\text { character? } \\
\text { cherent from the stereotyped female character in video } 1 \text { ? }\end{array}$ \\
\hline
\end{tabular}

The exploration of questions on the gender issues in video 3, Timun Mas led the students to the discussion of a different characteristic of girls i.e. more resourceful (active, brave, having initiative), but seemingly non-conforming. This brought the students to further discuss about the societal expectation of girls and boys as well as the pros and cons which were possible to be included in the discourse.

The deployment of Contextual Learning which related the gender issues in Indonesian folktales in EFL class in this study has enabled students to relate folktales, which are often regarded as traditional and old, to their daily life experience. Moreover, the students seemed to get new insight in their interaction with Indonesian folktales. It has been known from the interview that most of the students were only familiar with some popular folktales such as Bawang Putih Bawang Merah, Malin Kundang, and Sangkuriang. In addition, folktales were also in connotation with traditional values with its dichotomy of good and bad. The contextual learning gave students new understanding that folktales can represent aspects of human life and seemingly old stories could be related to contemporary phenomena in the society. Since the characters and the interaction amongst characters in the stories implied more than merely the lesson of good and bad.

In relation to the EFL in the classroom, discussing topics which were closely related to students' daily life seemed to be interesting and encouraging student to be active exploring their English. With the active encouragement and stimulus from the teacher the students tried to use 
English in retelling stories from the video, describing the characters, describing people they were familiar with, as well as discussing and expressing their ideas to answer the questions on the gender issues. Not only the vocabularies used in describing characters, but also the expression used in the discussion such as the expression used in conveying ideas, agreeing and disagreeing enriched the students' experience of language use. Gender issues were quite new topic the students had in class, and the seemingly limited English they used did not discourage them to be involved in the learning process. This shows that when students learn what they are interested in, they are motivated to get involved. This is in line with previous studies by [17] and [18] which confirm that the leaners' interest on the topics in EFL classroom helps them built their engagement in classroom activities.

Moreover, the new understanding about gender in Indonesian folktales and its contextualization in daily life is valuable for students to make them aware of gender issues in other aspects of their life. By exploring gender issues in traditional literature and the discussion of the issue in EFL classroom, students have obtained new circumstance to enhance their language skills as well as their critical thinking and awareness on cultural and social aspects in their society.

\section{Conclusion}

There has been the imprudent perception that it is only women who deal with the issues on gender within their realm, and that such issues are not of importance or of interest to men.

This study shows that gender issues are inclusive, and the exploration of gender issues using the media of Indonesian folktales has also shown that the gender issues are very possible to be explored using both the male and female lens. Further, the blend of folktales as teaching media and EFL classroom for young adults allows students to think critically and reflect about aspects of life in their own communities, while enhancing their language skills. This study confirms the advantage of teaching ELT which encompass not only linguistic elements but also the integration of traditional literature in the curricula.

This study is still far from being comprehensive, due to the limitation of the variables and the scope $\mathrm{f}$ analysis. Therefore, more valuable result would be obtained by exploring different sources of literature as well as other teaching media and aspects of learning.

\section{References}

[1] J. Zipes, Fairy Tales and the Art of Subversion: the Classical Genre for Children and the Process of Civilization, 2nd editio. New York: Routledge, 2006.

[2] C. E. Citraningtyas, “Children's Literature, an Almost Forgotten Soil," Polyglot, vol. 1, no. 1 , pp. $38-47,2006$.

[3] G. Lazar, "Literature and language teaching: A guide for teachers and trainers," Cambridge: CambridgeUniversity Press, 1993.

[4] M. Bunanta, Problematika Penulisan Cerita Rakyat untuk Anak Indonesia: Telaah Penyajian dengan Contoh Dongeng Bertipe Cerita Cinderella. Jakarta: Balai Pustaka, 1998.

[5] J. Kuo, "Gender Bias in Folktales," TESL J., vol. XI, no. 11, 2005.

[6] J. Zipes, Why Fairy Tales Stick The Evolution and Relevance of a Genre, 1st editio. New York: Routledge, 2013.

[7] N. Bengtsson, "Sex and Violence in Fairy Tales for Children," Int. Child. Lit., vol. 47, no. 3, pp. 15-21, 2009. 
[8] Sunarto, "Analisis Wacana Kekerasan Terhadap Wanita dalam Cerita Dongeng Indonesia," Semarang, 2002.

[9] M. Tatar, The Hard Facts of the Grimms' Fairy Tales. New.Jersey: Princeton University Press, 2003.

[10] M. Maybin, J. \& Pearce, "Literature and creativity in English," in The art of English: Literary creativity, S. Goodman \& K. O’Halloran (Eds.), Ed. Basingstoke: Palgrave Macmillan and the Open University, 2006, pp. 3-48.

[11] S. L. McKay, "Literature as content for ESL/EFL," Internet TESL J., vol. XI, no. 11, 2001.

[12] SM Lwin, "Promoting language learners' cross-cultural awareness through comparative analyses of Asian folktales," TEFLIN J., vol. 27, no. 2, pp. 166-189, 2016.

[13] E. B. Johnson, Contextual Teaching and Learning: What It Is and Why It's Here to Stay. London: Corwin Press, 2002.

[14] Q. Masykuroh, "Girlhood and feminine ideals: linguistic representation of femininity in indonesian folktales," Humanit. Soc. Sci. Rev., vol. 7, no. 3, pp. 356-361, 2019.

[15] H. R. W. T. Citraningtyas, Clara Evi, Rudy Pramono, "An Old Folktale Reconstructed for Better Generation: An Indonesian Case," in Proceeding of MTAR, 2014, pp. $267-$ 275.

[16] R. K. T. Sarumpaet, "Batu Permata Milik Ayahanda: Dongeng Traditional Indonesia," J. Peremp., vol. 54, pp. 74-85, 2007.

[17] N. S. Yashima T., Ikeda M., "Talk and Silence in an EFL Classroom: Interplay of Learners and Context," in The Dynamic Interplay between Context and the Language Learner, King J., Ed. London: Palgrave Macmillan, 2016.

[18] E. Ushioda, "Language learning motivation through a small lens: A research Agenda," Lang. Teach., vol. 49, no. 4, pp. 564-577, 2016. 